\section{Inactivation of Isoniazid by Peroxidase}

INVESTIGATIONS on enzymes of Mycobacteria reported from this laboratory ${ }^{1}$ and elsewhere ${ }^{2,3}$ have shown the importance of cellular peroxidase for the activity of isoniazid. Results of an extension of these studies bearing on the effect of peroxidase on the tuberculostatic activity of isoniazid form the basis of the present communication.

Using Mycobacterium tuberculosis $H 37 R v$ as the test organism, growth studies were carried out on Youman's medium (without serum) and the observa. tions were made usually at the end of three weeks incubation at $37^{\circ} \mathrm{C}$. Horse-radish peroxidase (obtained through the courtesy of Dr. E. F. Hartree, Molteno Institute of Biology and Parasitology, Cambridge), beef-liver catalase (Boehringer) and mammalian cytochrome $c$ (Boehringer) were sterilized by Seitz filtration, whereas hæmin (Roche), hæmoglobin (Difeo) and isoniazid (Roche) were autoclaved ; 0.05 c.c. of the test organism, grown for 10 days on Dubos 'Tween' albumin medium, was used as the inoculum per tube.

Table 1. EFFECT OF PRROXIDASR AND RETAATED COMPOUNDS ON GROWTH-INHIBITION OF Mycobacterium tubereulosis H37Rv BY IsONIAZID

\begin{tabular}{|c|c|c|c|c|c|c|c|c|c|}
\hline \multirow{2}{*}{ Supplement } & \multirow{2}{*}{$\begin{array}{l}\text { Conc. } \\
\gamma / \text { c.c. }\end{array}$} & \multicolumn{8}{|c|}{ Isoniazid ( $\gamma /$ c.c.) } \\
\hline & & 0 & 0.05 & $0 \cdot 1$ & 0.5 & 1 & 5 & 10 & 25 \\
\hline None (control) & & + & + & - & - & - & - & - & - \\
\hline Peroxidase & & + & + & + & + & + & + & + & + \\
\hline & $\begin{array}{l}1.5 \\
0.6\end{array}$ & \pm & $\begin{array}{l}t \\
t\end{array}$ & + & $\begin{array}{l}+ \\
+\end{array}$ & $\stackrel{+}{+}$ & + & \pm & $\bar{z}$ \\
\hline & 0.3 & + & + & + & + & + & + & - & - \\
\hline & 0.15 & + & + & + & + & + & - & - & - \\
\hline & 0.03 & + & + & + & + & + & - & - & - \\
\hline Peroxidase & 0.010 & + & + & + & + & & - & & \\
\hline (inactivated) & 3 & + & + & - & - & - & $\overline{-}$ & $\overline{1}$ & - \\
\hline Hæmin & $\begin{array}{r}10 \\
5\end{array}$ & + & $\stackrel{t}{t}$ & $\stackrel{t}{t}$ & $\begin{array}{l}+ \\
+\end{array}$ & $\stackrel{t}{+}$ & + & \pm & \pm \\
\hline & $2 \cdot 5$ & + & + & + & + & $\div$ & - & - & - \\
\hline & 1 & + & + & + & + & - & - & - & - \\
\hline Catalase & $10^{0 \cdot 5}$ & + & \pm & $\bar{z}$ & 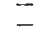 & - & - & $\overline{-}$ & - \\
\hline Hæmoglobin & 10 & + & + & - & - & - & - & - & - \\
\hline Cytoehrome $c$ & 10 & + & + & - & - & - & - & - & - \\
\hline
\end{tabular}

The mean results of several experiments are summarized in Table 1. Fisher first demonstrated, later confirmed by Knox ${ }^{5}$, that hæmin strongly antagonized isoniazid. It was further shown that it breaks up isoniazid to diiso-nicotinoyl-hydrazine and iso-nicotinic acid ${ }^{6,7}$. In the present study, it is seen that while on a weight basis peroxidase is 100 times as active as free hæmin, on the basis of its hæmin content, which is 2.5 per cent, it is 4,000 times more active. The fact that inactivated (autoclaved) peroxidase showed no effect indicates that the reaction is enzymatic and specific, since the other hæm-proteins were without activity.

These experiments were carried out with extracellular peroxidase. Isoniazid-susceptible tubercle bacilli have, however, the peroxidase at the surface and intracellular. Thus, isoniazid could be fixed to the bacteria and broken down within the cell. If the breakdown products are liberated outside by extracellular peroxidase, they may not enter the bacterial cell.

Much work has been done on the possible modes of the action of isoniazid. Investigations of our own demonstrated that isoniazid does not act by inhibition of either catalase or peroxidase ${ }^{8}$, and we proposed a mechanism by which isoniazid is fixed to susceptible cells and metabolized with a peroxidase-oxidase system ${ }^{9}$ similar to that of tryptophan proposed by Knox and Mehler ${ }^{10}$.

That the activity of isoniazid may be due to its breakdown to peroxide is not supported by the fact that the more peroxide-susceptible, catalase-negative mutants are, on the contrary, resistant to the drug. Further, the action of peroxidase is also not merely due to its removal of peroxide, since otherwise catalase should have been equally effective.

These studies emphasize that the breakdown products of isoniazid, other than peroxide, eventually exert the inhibitory effect by blocking an essential function once they are transported across the cell membrane into the cell.

$$
\begin{aligned}
& \text { M. O. Tirunarayanan * } \\
& \text { W. A. Vischer* }
\end{aligned}
$$

Medical Section,

Schweiz. Forschungsinstitut für Tuberkulose,

Davos.

Dec. 22.

* Present address : c/o J. R. Geigy S.A., Basle, Switzerland.

${ }^{1}$ Tirunarayanan, M. O., and Vischer, W. A., Amer. Rev. Tuberc. $75,62(1957)$

andrejew, A., Gernez-Rieux, Ch., and Tacquet, A., Ann. Inst. Pasteur, 91, 586 (1956).

3 Hedgecock, L. W., and Faucher, I. O., Amer. Rev. Tuberc., 75, 670 (1957).

4 Fisher, M. W., Amer. Rev. Tuberc., 69, 469 (1954).

${ }^{5}$ Knox, R., J. Gen. Microbiol., 12, 191 (1955).

'Krüger-Thiemer, E., Naturwiss., 42, 47 (1955).

'Albert, A., and Rees, C. W., Biochem. J., 61, 128 (1955).

${ }^{8}$ Tirunarayanan, M. O., and Vischer, W. A., Naturwiss., 43, 474 (1956).

- Tirunarayanan, M. O., and Vischer, W. A., Naturwiss., 44, 11 (1957).

${ }^{20}$ Knox, W. E., and Mehler, A. H., J. Biol. Chem., 187, 419 (1950).

\section{Quantitative Estimation of Purines by the Visual Scanning of Photographs of Paper Chromatograms}

Estimation of microquantities of purines by paper chromatography was first suggested by Hotchkiss ${ }^{1}$. Later, detection by photographing with an ultraviolet source has amplified the method ${ }^{2}$. Tennent et $a l .^{3}$ and others have designed adaptors for the Beckman spectrophotometer to enable direct estimation of the purines from paper chromatograms. This method requires costly instrumentation, and is timeconsuming unless an automatic recorder is provided.

Other authors have estimated the size of the spot 4 produced on the photograph.

To obtain a quantitative relationship between area and concentration it is necessary that a spot of accurate dimensions be placed on the starting line. This is frequently difficult. We have been able to produce quantitative results by the scanning of photographs on an automatically recording (visual) densitometer designed by us and reported in detail in a subsequent paper. The densitometer has a high sensitivity, which enables density as well as area definition to be recorded.

Fig. 1, showing typical calibration curves of adenine and adenosine, was obtained by the following method. The standards $0.02,0.04$ and 0.08 umole of the substance were spotted on to Whatman No. 1 paper. The three concentrations were developed on the same paper with iso-propyl ether, 90 per cent $(w / v)$ formic acid, $(3: 2)^{5}$ for $6 \mathrm{hr}$. by the ascending technique. The papers were then dried and photographed by contact photography on to 'Kodagraph' contact paper (extra thin) using a B.G.E. germicidal lamp to produce the image ${ }^{6}$. The print was slightly overexposed to ensure an even black background. 